\title{
Green Computing Practices \\ as a Part of the Way to the Sustainable Development
}

\author{
Zuzana Bezáková \\ University of SS. Cyril and Methodius, Faculty of Mass Media Communication, \\ J. Herdu 2, 91701 Trnava, Slovak Republic \\ zuzana.bezak@gmail.com
}

\begin{abstract}
Sustainable development is now often mentioned in connection with the further direction of our planet, our economy and the overall human consumption. That is the reason why the companies come with various types of innovation. The use of information technology is now an essential part of our life, our business, our marketing. This area of using computers and their information technology equipment requires a new - greener approach. This post reflects the need for sustainable computing and different approaches to its implementation to the business. We deal with the categorization of green computing performance metrics. One factor of green computing is also the customer and what he wants. Focus on customers' requirements forced the companies to look to the markets and customers as the main drivers of their business in the area of sustainable computing. The contribution also includes the results of the research of Slovak companies approach to sustainable computing in the Slovak business environment.
\end{abstract}

Keywords: sustainable development, sustainable computing, green computing, innovation.

\section{Innovation and Sustainable Development}

The concept of innovation evokes in many groundbreaking technological inventions that are the result of long-term activities and research work of scientists. However, innovation can occur in any business, and there is an effort to success in the market, be faster than its competitors, and also to offer products that satisfy customers. Innovation need not be oriented only to products but also to services, or processes, or marketing practices [1]. Creation and management of innovation processes are included with all its principles in the full range of corporate governance [2].

Much attention has recently been devoted to innovation as a means of achieving a radical improvement of the system of corporate environmental practices and performance. Eco-innovation is perceived as key concept that provides direction and vision for tracking overall societal changes necessary to achieve sustainable development [3].

We can harness the power of IT to solve environmental problems but also try to make our IT systems and their use greener. Green IT, also known as green computing is the study and practice of designing, manufacturing and use of computers, servers, 
monitors, printers, storage devices, and networking and communications systems effectively and efficiently, with no or minimal impact on the environment. Green IT is used as a support for other environmental activities and help to create green awareness. Thus, green IT includes hardware, software, tools, strategies and practices that improve and promote environmental sustainability.

Green IT benefits the environment by improving energy efficiency, reducing greenhouse gas emissions, using less harmful materials, the re-use and recycling is also important. Thus, green IT includes the dimension of environmental sustainability, economics energy efficiency and total cost of ownership, which includes the cost of disposal and recycling. Increased awareness of the harmful effects of greenhouse gas emissions, new stringent environmental legislation, concerns about procedures for handling electronic waste and concern about corporate image are the driving force for businesses and individuals to become green [4].

Currently available sources talking about sustainability present three broad environmental objectives leading to sustainability:

1. Eco-efficiency - the supply of goods and services at competitive prices to satisfy human needs and bring quality of life, while progressively reducing ecological impacts and resource intensity throughout the life cycle in accordance with the earth's carrying capacity

2. Eco-equity - means equality between people and generations, and equal rights of all people to natural resources

3. Eco-effectiveness - considered the best solution to environmental problems, but requires a shift in thinking and transforming business models. People need to stop environmental degradation and depletion of non-renewable resources [5].

The most significant impacts on the company's ability to behave sustainably include:

- social impact - this is a measurement of the impact of the enterprise in terms of the social contract and the impact of interest groups

- environmental impact - the effect of business activities on the geophysical environment

- organizational culture - involves the relationship between the company and internal stakeholders, particularly employees, and all aspects of the relationship

- finance - are evaluated in terms of adequacy of compensation for assuming the risk.

It is necessary to find a balance between the influences that will ensure not only sustainability, but also sustainable development. The sustainable development is the new view for business, it is a change of the established practices. Addressing sustainability in the business area brings number of sub-issues.

The basic features are:

- $\quad$ sustainable production

- sustainable consumption

- sustainable marketing

- $\quad$ sustainable profit [6]. 


\section{Green Computing}

Green computing can be included in the field of sustainable consumption, in terms of access of business entity to sustainable development. It can be defined as the use of computer resources efficiently in practice. It is important that the initiative of green computing was systemic in nature and was designed to address increasingly sophisticated problems. Green computing refers to the requirements of environmental protection and energy saving together with the reduction of operational costs in today's increasingly competitive world. But before it comes to implementation, it is also important to deal with what kind of energy and performance gains can be achieved through it. Therefore, analysis of what we have today and what we have to do is essential and important for achieving the benefits of green computing [7].

Governments of various countries are increasingly pushing for the adoption of green computing and sustainable IT investment and sustainable practices. Due to the immediate impact on business value, it is likely that green computing will continue to focus some time to reduce costs while improving the efficiency of data centers and desktops [8].

IT can be a key factor in greening even other sectors and also the initiator of positive initiatives towards environmental sustainability. Positive change in IT should be reflected in the change of environment. Several studies show that IT contributes only about $3 \%$ of greenhouse gas emissions to the total quantity, this means that the vast majority of emissions come from non-IT resources.

Green IT can help create a better environment through these tools, technologies and systems:

- Software tools for analysis, modeling and simulation of environmental impacts and risk management environment

- Platform for eco-management, emissions trading and ethical investment

- Tools for auditing and reporting energy consumption and savings and for monitoring greenhouse gas emissions

- Environmental knowledge management systems, designed for the collection and transmission of environmental knowledge, support systems, environmental ontology

- Environmental engineering systems, including geographic information systems

- Urban planning tools and systems environment

- Technologies and standards for interoperable environment monitoring networks, intelligent sensor networks

- Integration and optimization of existing environmental monitoring networks, easy to plug-in new sensors, Sensors cooperation and networking

- Tools and systems to optimize business processes in organizations.

To reduce their carbon footprint, organizations can dematerialize some of their products and activities, using IT. Dematerialization refers to the transformation of the physical goods Information goods represented in digital form, so-called "Turning atoms to bits" [4]. 


\section{Sustainable Approach to Hardware and Software}

\subsection{Green PCs, Laptops and Servers}

Every company can significantly reduce electricity consumption by making small changes in the way the computer is used. Energy cost savings of one computer does not seem to be an important item, but combined savings of hundreds of computers in the enterprise is already considerable and is not negligible. PC power consumption can be reduced by adopting several measures:

- Enabling power management features

- Turn off the system when not in use

- Use a screen saver

- The use of thin client computers.

These measures will not become a reality without the sincere willingness of users and their active participation. Wise companies tend to adopt innovative environmental strategies, create value and build competitive advantage through innovation in the field of computing [4].

\subsection{Green Data Centers}

Green data centers (DC) are those in which the computer system, air conditioning, electrical and mechanical systems, which cover data centers are designed and operated for maximum energy efficiency, low carbon footprint and minimal environmental impacts. Operators who want to optimize the energy efficiency of datacenters, have many options to choose from, but usually cannot know in advance exactly identify potential savings before investing. Also, it is very difficult to determine in advance the actual risk of the new approach in a real environment. It is therefore important that the operator can evaluate DC savings, but also the risks of several options before making a choice. For this purpose there are various simulation systems, such as The EoDD (Energy Optimized Data Center Designer) [9].

Performance metrics for green computing data centers can be divided into two categories: basic metrics and advanced metrics.

Basic metrics provide a basic picture of the data center. These include:

- Metrics of greenhouse gas

- Metrics of humidity

- Thermal metrics

- Metrics of Power.

Advanced metrics provide a deeper look at the data centers, and include:

- Multiple indicators

- Total cost of ownership.[10] 


\subsection{Green Cloud Computing}

Cloud computing delivers infrastructure, platform, and software (applications) as services that are available to consumers in the pay-as-you-go model. In the industry, these services are referred to as Infrastructure as a Service (IaaS), Platform as a Service (PaaS) and software as a service (SaaS). Many providers of computing services, including Google, Microsoft, Yahoo, and IBM quickly deploy data centers in different locations around the world, to be able to deliver cloud computing services [11]. In the cloud computing world, IT capabilities are delivered on the fly and on-demand through the Internet when the need arises, instead of drawing from desktop computers. Many design and architectural patterns are emerging around cloud computing that make it difficult to fit everything into a perfect definition [12].

\subsection{Green Data Storage}

Data and information storage requirements are growing constantly. Storage systems in data centers consume large amounts of energy for running and cooling. For example, in a data center, storage systems consume $24 \%$ to $40 \%$ of total energy consumption of IT and are the largest centers of power. In addition to the requirements for energy-efficient servers, there is currently the focus on the greening of data storage. Energy management of data storage can be divided into two basic areas: hard-disk energy management and system-level energy management among the various main storage devices, which include hard disk drives, magnetic tape drives and solid state drives, consume more power than tape and SSD. The main techniques for dealing with the energy of individual disks are transitioning state, caching and dynamic rotations per minute (DRPM). System-level energy management is about system-wide management across different or multiple components or devices. Energy management techniques for redundant array of independent disks (RAID) systems, tiered storages, virtualized storage and cloud storage are in this category.

Green data storage is a priority for many European storage professionals, and some of them have begun to implement measures to cut energy usage. Green storage considerations are important when buying storage hardware. Many users would pay extra money for more energy-efficient hardware [13].

\subsection{Green Software}

Green software is the result of innovation process towards sustainability. Innovation is the successful introduction of new product, service, or process. Software innovation can be seen as a process leading to:

- development of a novel aspect, feature or application of an existing software product or process, or

- introduction of a new software product, service or process or an improvement in the previous generation of the software product or process, and

- entry to an existing market or the creation of a new market [14]. 
Innovated software is an important element in determining the total energy consumption and computational efficiency. Software is a key element in improving environmental sustainability. Green software is software that is environmentally friendly, and especially helps in improving the environment. Green software can be divided into four categories:

- software that is environmentally friendly, uses less energy to run

- embedded software that helps other things being green

- sustainability reporting software, or carbon management software (CMS)

- software for understanding climate change, assess its impact [4].

\subsection{Green Networks and Communication}

Networking and communication play more important role than ever before, and facilitate the transfer and sharing of data. It allows us to communicate and share information, trade, learn and socialize online, so that we can more effectively use our working time, and also can do many other things. Green Network shows ways to minimize the impact of networks on the environment through energy-efficient network technologies, protocols and products, and minimize the use of resources. Procedures of green networks include the following:

- the use of newer, more energy-efficient techniques, technologies and products

- update of older devices and replacing them with newer, greener network devices

- the use of intelligent systems, user management and energy conservation through networks to improve energy efficiency

- the use of remote management and video conferencing instead of traveling [4].

\section{Sustainable Computing in the Slovak Business Environment}

We have made the research dedicated to the point of view of Slovak business entities to sustainable computing. The aim of our research was to find out what are the attitudes of Slovak companies to sustainability but mainly to sustainable computing /sustainable use of PC/. We also examined whether there are specific activities in this area, to which the companies are dedicated. The results should give us an idea of the current state, so we can propose solutions to improve the routing of these companies towards sustainable computing and thereby protect the environment. Also, we wonder whether sustainable computing is an important factor from the point of view of the competitiveness in Slovak business environment and what is the position of the customer in this process.

The survey included 45 Slovak IT companies, advertising agencies and web hosting companies that deal with domain registration, web hosting, online marketing, network management, network solutions, etc.

We focused on small $/ 80 \% /$ and medium enterprises $/ 20 \% /$. The reason was, that [15] in Slovakia recently grows importance of small companies. Their advantage is that they mostly focus on one segment, which can adapt well their marketing mix. 
$79 \%$ of respondents consider their business as sustainable, but this behavior is rather linked with activities such as recycling paper, waste separation, use of electronic invoices and so. We also found that most companies $/ 80 \% /$, which indicate their behavior as sustainable, use the devices - PC, network solutions that are friendly to the environment.

Survey results indicate that these efforts are related to the saving of electricity, which is beneficial to society, but of course it has a positive impact on the environment.

Eco attribute of the device for which they decide in purchase are in favor of ecologic devices only in $27 \%$. Another respondents do not consider this fact as important $133 \%$, while others argue that the price is mainly important when buying a particular device $133 \%$ /.

As mentioned in the article, the energy consumption can be reduced through simple procedures. Most companies /93\%/ use at least one procedure to reduce electricity consumption, including the most frequently used such as screen saver, standby PC when it is not in use, or even a complete system shutdown. Just in one case they intentionally use the thin client computers or laptops that have lower power consumption compared to PC.

The status of the customer in the process of sustainable computing is very important. The term "Green Company" is not seen as a big advantage $173 \%$ / in the Slovak business environment.

Customers are not actively interested in environmental aspects of solutions $/ 87 \% /$, Slovak companies meet this interest very rarely $/ 13 \% /$.

Websites are important for the presentation, and also in attracting new customers. The trend is that larger companies are dedicated to their websites and presentation of sustainable behavior, social responsibility, thus helping to improve the environment. Even small and medium-sized companies in our survey indicate in some cases their green activities on websites $/ 27 \% /$, but for many of them it is not at all important to give this information to the customer $/ 47 \% /$. Some companies plan to publish such information on the website $/ 13 \% /$. Of course, companies that do not perform any environmental activities, cannot advertise them $/ 13.3 \% /$.

\section{Conclusions}

Sustainable IT services are essential for the success in business. They not only focus on data center efficiency and on minimizing carbon emissions. They are aimed directly at the long-term importance of IT for the organization, its customers and for the whole society. Therefore sustainable computing refers to everything what the organization needs to do in order to ensure that IT services will provide excellent value to achieve a strong market position and ability to secure its survival. It is important to align IT with the business strategy to achieve market-leading business value, customer value and societal value. This will ensure the viability of IT within the organization. We define sustainable social services in total value terms as the total amount that is available to the company. Systematic integration and alignment of IT services is important in terms of creating greater social value [8]. Companies should 
know wishes and needs of customers. It is important to have enough information about them and then use them in their business [16].

The results of the survey show that Slovak companies are trying to implement green approach in the use of hardware and sustainable computing /sustainable use of computers/. Companies themselves do not consider this fact as a competitive advantage in the Slovak business environment. They try to use devices that are environmentally friendly, or trying to use simple procedures to reduce electricity. Also, quite a lot make extensive use of other technical equipment, but also networking solutions that are environmentally friendly.

Based on the survey results, we can conclude that the customer is not an important factor in sustainable computing in Slovakia. The customer is not very interested in greener solutions which are probably the reason why there is even a small degree of companies' promotion of their green activities on the site.

An interesting solution and recommendation is:

- Draw customers into the green activities of the company, gradually acquaint with the importance of sustainable behavior.

- The use of organic labeling and explaining the importance of the environmental behavior importance may lead to an overall improvement of the environment.

- More frequent use of advertising "slogans" with the sustainable theme can help you to become more and more to receive this concept to the attention of the customer

- To offer organic solutions and services and IT solutions, offer sustainable computing initially only as an added value.

These measures can help in the Slovak business environment to build a solid foundation for sustainable use of computers, strengthen the importance of this concept for companies, but especially the need to build sustainable behavior of the customer.

Acknowledgements. This article has been elaborated within the project VEGA 1/0900/12 - "Improving innovation performance and innovation entities through a system of open innovation with support of integrated marketing communication".

\section{References}

1. Zaušková, A., Domová, J.: Inovačná schopnost' a inovačná výkonnost' podnikatel'ských subjektov. UCM Trnava, Trnava (2012)

2. Zaušková, A., Miklenčičová, R.: Tvorivost' v inovačnom procese. In: Trvalo udržatel'ný rozvoj regiónov a podnikov pomocou inovatívnych a zelených technológií: zborník príspevkov z medzinárodnej vedeckej konferencie uskutočnenej v rámci projektu ITMS 22410420018, 204-213. UCM Trnava, Trnava (2012)

3. Sustainable Manufacturing and Eco-Innovation, http: / / www . oecd. org

4. Murugesan, S., Gangadharan, G.R.: Harnessing Green It. Willey. IEEE (2012) 
5. Information systems and environmentally sustainable development: Energy informatics and new directions for the IS community, http: / / terrypress.terry .uga. edu

6. Šmida, L., Hrdinová, G., Sakál, P.: Predpoklady budovania spoločensky zodpovedného podnikania ako súčasti udržatel'nej spoločnosti v zmysle konceptu udržatel'ného rozvoja. In: Transfer inovácií 21/201, pp.198-203. Košice (2011)

7. Green computing: Practice of Efficient and Eco-Friendly Computing Resources, http: / / www. sersc.org

8. Sustainable IT services: Assessing the impact of green computing practices, http: / /www.sis.pitt.edu

9. Capabilities and Limitations of Direct Free Cooling in Data Centers, http: / / www. fhnw. ch

10. Review of performance metrics for green data centers: a taxonomy study, http: //sameekhan.org

11. Energy-aware resource allocation heuristics for efficient management of data centers for Cloud computing, http: / /www. sciencedirect. com

12. Green Computing, A.: Dual Technology for Cloud Computing and HPC, http: / /www. computer.org

13. Green data storage technology survey: Green storage a priority for European storage professionals, http: / / www. computerweekly. com

14. Lippoldt, D., Stryszowski, P.: Innovation in the Software Sector, pp. 10, 185 p. OECD (2009)

15. Č́ayová, L.: Benchmarkingové porovnávanie v oblasti marketingovej komunikácie. FMK UCM Trnava, Trnava (2009)

16. Matúš, J., Čábyová, L., Ďurková, K.: Marketing - základy a nástroje. FMK UCM Trnava, Trnava (2008) 